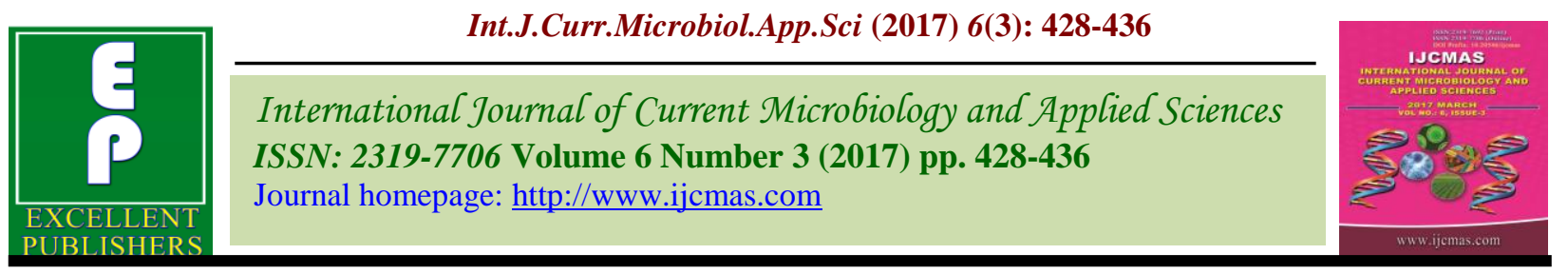

Original Research Article

https://doi.org/10.20546/ijcmas.2017.603.049

\title{
Soil Physical Properties and Productivity as Influenced by Soil Moisture Conservation Measures under Maize Based Cropping System in Acid Soils of North East India
}

\author{
Bidyapati Ngangom ${ }^{1 *}$, Anup Das ${ }^{2}$, Savita $^{2}$ and R. Krishnappa ${ }^{2}$ \\ ${ }^{1}$ Department of Agronomy, Uttar Banga Krishi Viswavidyalaya, Pundibari, Cooch Behar- \\ 736165, West Bengal, India \\ ${ }^{2}$ Division of Crop Production, ICAR Research Complex for NEH Region, Umiam, Meghalaya, \\ India \\ *Corresponding author
}

\begin{abstract}
A B S T R A C T
\section{Keywords}

Soil moisture conservation, Crop residue mulch, Water holding capacity, Maize equivalent yield, North Eastern Hill region.

Article Info

Accepted:

10 February 2017

Available Online:

10 March 2017

Prevalence of moisture stress and poor crop establishment are major constraints for the cultivation of rabi crops in maize fallows which results in reduced cropping intensity and insufficient food production in North Eastern Hill region. Hence, the present field experiment was conducted with different maize based cropping systems under diverse soil moisture conservation (SMC) options at mid-altitudes of Meghalaya. Results revealed that cultivation of black gram after preceding maize crop with retention of maize stalk+Tephrosia purpurea mulching increased the soil moisture content followed by maize - pole type French bean with maize stalk+Tephrosia purpurea. Application of Maize stalk+Ambrosia artemisiifolia and maize stalk+Tephrosia purpurea decreased soil BD and increased water holding capacity (WHC) substantially. Besides, Maize-black gram $\left(\mathrm{CS}_{5}\right)$ recorded lowest soil bulk density (BD) of $1.24 \mathrm{Mg} \mathrm{m}^{-3}$ whereas highest BD was being recorded in no mulch at all depths. There was significant $(76 \%)$ increase in WHC under maize-black gram cultivation than maize- fallow at $0-15 \mathrm{~cm}$, maximum WHC being recorded in maize stalk+Tephrosia purpurea at all the depths $(74.5,71.9$, and $70.3 \%)$. The highest maize equivalent yield was obtained from maize - pole type french bean under maize stalk+Tephrosia purpurea $\left(9.5 \mathrm{t} \mathrm{ha}^{-1}\right)$ followed by Maize stalk + Ambrosia artemisiifolia $\left(8.8 \mathrm{t} \mathrm{ha}^{-1}\right)$ soil moisture conservation measure.
\end{abstract}

\section{Introduction}

Mulching improves the soil physical condition by enhancing aggregation and conserving soil moisture by increasing infilteration, checking losses by evaporation and run off (Nalayini et al., 2009). The positive effect of conservation tillage and crop residues on soil physical quality and soil organic carbon pool are well established, only a limited number of studies have evaluated the interactive effects of residue application rates on overall soil physical quality under a range of tillage systems (Singh et al., 2013). The use of less tillage with increase residue preservation enhance water conservation and other benefits like decreasing soil erosion and increase organic matter content resulting in improved soil physical properties (Blanco and Lal, 2008). 
It is hypothesized that after the harvest of kharif crop, cultivation of short duration crops with residual moisture would enhance cropping intensity and water productivity in the region. In this background the present study was planned to investigate the effect of soil moisture conservation (SMC) practices on soil properties and productivity of rabi crops after harvest of maize.

\section{Materials and Methods}

A field experiment was conducted at the upland experimental block of Agronomy, ICAR Complex for NEH Region, Umiam, Meghalaya during the year 2012. The experimental site is located at $25^{\circ} 41^{\prime \prime} \mathrm{N}$ latitude and 91 $54^{\prime \prime}$ E longitude with an elevation of $980 \mathrm{~m}$ above mean sea level. The total rainfall received during crop period was $2052.5 \mathrm{~mm}$, the highest rainfall being received in the month of August $(440 \mathrm{~mm})$ and no rain received in December. The experiment was laid in three time replicated split plot design by selecting five maize based cropping sequences Viz., $\mathrm{CS}_{1}$ : Maize - fallow, $\mathrm{CS}_{2}$ : Maize- -rapeseed, $\mathrm{CS}_{3}$ : Maize- French bean (bush type-BT), $\mathrm{CS}_{4}$ : Maize-French bean (pole type- PT) and $\mathrm{CS}_{5}$ : Maize-black gram as a main plots and four soil moisture conservation (SMC) measures; $\mathrm{M}_{0}$-No mulch (residue removal), $\mathrm{M}_{1}$ - In-situ maize stalk mulch, $\mathrm{M}_{2}-\mathrm{M}_{1}+$ Ambrosia artemisiifolia (Rag Weed)@10 t ha ${ }^{-1}$ and $\mathrm{M}_{3}-\mathrm{M}_{1}+$ Tephrosia purpurea (White hoary pea)@10 t ha ${ }^{-1}$ were included as subplots. The maize was sown on $30^{\text {th }}$ April with all the recommended agronomic practices (Table 1).

The fresh biomass of Ambrosia artemisiifolia and Tephrosia purpurea were collected from nearby farm areas (road sides, wastelands, farm fences etc.). The fresh biomass was weighed and applied as mulch in between the rows of standing maize 20 days before the harvest of maize as per the treatment requirement. The recommended dose of fertilizers and seeds were placed in the furrows and covered with soil and the mulch materials (Table 1). The rabi crops of French bean (BT and PT) and blackgram were sown on $24^{\text {th }}$ August. After the germination of seeds, the maize stalks were cut and spread all over the field just above the mulches to cover the soil surface. This way, there were two layers of mulch i.e. maize stalk mulch and Ambrosia artemisiifolia/Tephrosia purpurea mulch to cover the soil surface.

\section{Soil sampling and analysis}

\section{Soil moisture}

The soil moisture content was recorded at different soil depths i.e., 0-15 cm, $15-30 \mathrm{~cm}$ and $30-45 \mathrm{~cm}$ at 15 days interval. Soil samples were collected from central spots of the plots in between the crop rows. The samples were dried in hot air oven at $105{ }^{0} \mathrm{C}$ for till the samples attained constant weight. To calculate moisture content of soil by gravimetric method the following formula was used (Jalota et al., 1998)

Soil moisture $(\%)=$

Weight of fresh soil-weight of oven dried soil

Weight of oven dried soil $\times 100$

\section{Soil moisture stock}

Soil moisture stock (SMS) was calculated at the flowering stages in all the crops. It was calculated with the following formula and expressed in $\mathrm{cm}$ per $45 \mathrm{~cm}$

SMS $=\frac{\text { SNC (96) }}{100} \times$ Bulk density $\left(\mathrm{Mg} \mathrm{m}^{-3}\right) \times$ Depth $(\mathrm{cm})$ 


\section{Bulk density}

Bulk density (BD) was determined by the core method (Blake and Hartge, 1986) using cores of $5.8 \mathrm{~cm}$ height and $5.4 \mathrm{~cm}$ diameter at 0-15 cm, $15-30 \mathrm{~cm}$ and 30-45 cm depth and oven dried at $105^{\circ} \mathrm{C}$ (one sample per plot).

\section{Water holding capacity}

Water holding capacity (WHC) was measured at three depths 0-15, 15-30 and 30-45 cm after the harvest of rabi crop. WHC was determined by using perforated can as described by Jalota et al., 1998 .

\section{Results and Discussion}

\section{Variation in soil moisture content}

Higher soil moisture content was recorded under maize-French bean (PT) system during earlier growth period. In particular, from 60 DAS to harvest, maize-blackgram recorded higher soil moisture content followed by maize-french bean (PT) as compared to other cropping systems (Fig. 1).

The higher soil moisture in maize-blackgram system might be due to its spreading canopy nature and broad leaves of blackgram which cover ground effectively and reduced exposure of soil surface to the sun directly and resulted in reduction of relentless evaporation from soil surface. Similar findings were reported by Obalum et al (2010) in soybean with special reference to growth habit. Among the SMC measures, maximum soil moisture content was recorded under $\mathrm{M}_{1}+$ Tephrosia purpurea and $\mathrm{M}_{1}+$ Ambrosia artemisiifolia mulch practices at all the crop growth stages and the lowest soil moisture content was found in no mulch (Fig. 2 ). The even distribution of crop residues on the soil surface which blocks the direct evaporation from soil reduces the surface runoff. Besides, it acts as an insulator for solar radiation and do not permit direct contact with soil, which avoid continuity of capillaries for the evaporation loss of water through soil profile (Rathore et al., 1998). Higher soil moisture content under mulched plots than the no-mulched plots at all the soil depth was also reported by Pervaiz et al (2009).

\section{Soil moisture stock}

The cropping systems exhibited significant effect on soil moisture stock recorded during crop growth (Table 2). Maximum soil moisture stock was recorded under maizeFrench bean (BT) system $(21.4 \mathrm{~cm} / 45 \mathrm{~cm})$ which was significantly higher compare to maize-rapeseed system $(17.3 \mathrm{~cm} / 45 \mathrm{~cm})$. There was $24 \%$ higher soil moisture stock under maize-French bean (BT) system than maize- rapeseed system. The soil moisture stock of different cropping system in descending order were maize- French bean (BT) $(21.4 \mathrm{~cm} / 45 \mathrm{~cm})>$ maize-black gram $(19.8 \mathrm{~cm} / 45 \mathrm{~cm})>$ maize-French bean $(\mathrm{PT})$ $(19.8 \mathrm{~cm} / \mathrm{cm})>$ maize-fallow $(19.7 \mathrm{~cm} / 45 \mathrm{~cm})$ $>$ maize- rapeseed $(17.3 \mathrm{~cm} / 45 \mathrm{~cm})$ cropping system.

The SMC measures had significant influence on soil moisture stock at flowering stage. The highest soil moisture stock was found with the retention of $\mathrm{M}_{1}+$ Tephrosia purpurea mulch $(20.5 \mathrm{~cm} / 45 \mathrm{~cm})$ which was $11 \%$ higher than no mulch. The soil moisture stock under $\mathrm{M}_{1}+$ Tephrosia purpurea mulch, $\mathrm{M}_{1}+$ Ambrosia artemisiifolia mulch and in-situ maize stalk mulch were at par among them but remained significantly superior to no mulch. Sharma $e t$ al (2010) observed significant contribution of mulching in succeeding crop after maize towards enhanced nutrient supply particularly $\mathrm{N}$, besides higher soil moisture content in the early growth stages. 
Table.1 Input and cultural practices followed for the experiment

\begin{tabular}{|c|c|c|c|c|c|}
\hline Particulars & $\begin{array}{c}\text { Maize } \\
\text { (Zea mays L.) }\end{array}$ & $\begin{array}{c}\text { Rapeseed } \\
\text { (Brassica } \\
\text { compestris L.) }\end{array}$ & $\begin{array}{c}\text { French bean } \\
\text { (bush) [Phaseolus } \\
\text { vulgaris L.] }\end{array}$ & $\begin{array}{c}\text { French bean (pole) } \\
\text { [Phaseolus vulgaris } \\
\text { L.] }\end{array}$ & $\begin{array}{c}\text { Black gram } \\
\text { (Vigna mungo } \\
\text { Viridis) }\end{array}$ \\
\hline Variety & DA-61A & TS-46 & Arka anoop & Naga local & PD-4 \\
\hline Date of sowing & $30^{\text {th }}$ April & $21^{\text {st }}$ September & $24^{\text {th }}$ August & $24^{\text {th }}$ August & $24^{\text {th }}$ August \\
\hline Spacing $(\mathrm{cm})$ & $60 \times 20$ & $30 \times 5$ & $30 \times 15$ & $30 \times 15$ & $30 \times 10$ \\
\hline FYM & $5 \mathrm{tha}^{-1}$ & - & - & - & - \\
\hline $\begin{array}{l}\text { Fertilizer doses }\left(\mathrm{N}: \mathrm{P}_{2} \mathrm{O}_{5}: \mathrm{K}_{2} \mathrm{O}\right. \\
\mathrm{kg} / \mathrm{ha})\end{array}$ & $60: 60: 40$ & $60: 60: 40$ & $50: 60: 40$ & $50: 60: 40$ & $20: 60: 40$ \\
\hline Gap filling (DAS) & 10 & 10 & 8 & 8 & 12 \\
\hline \multirow{2}{*}{ Hand weeding (DAS) } & 25 & 25 & 20 & 20 & 20 \\
\hline & 45 & 50 & 40 & 40 & 40 \\
\hline Top dressing of $\mathrm{N}$ (DAS) & 30 & 30 & - & - & - \\
\hline Pesticide application (DAS) & Round up $3 \mathrm{G}$ & - & - & - & - \\
\hline Date of harvesting & $9^{\text {th }}$ August & $16^{\text {th }}$ December & $2^{\text {th }}$ November & $16^{\text {th }}$ November & $1^{\text {st }}$ December \\
\hline
\end{tabular}


Table.2 Effect of cropping systems and soil moisture conservation measures on SMS at flowering stage, soil bulk density and WHC of rabi crops

\begin{tabular}{|c|c|c|c|c|c|c|c|}
\hline \multirow{2}{*}{$\begin{array}{l}\text { Treatments } \\
\text { Cropping Systems }\end{array}$} & \multirow{2}{*}{$\begin{array}{l}\text { SMS } \\
\left(\mathrm{cm} \mathrm{45}^{-1}\right) \\
\left.\mathrm{cm}^{-1}\right)\end{array}$} & \multicolumn{3}{|c|}{ WHC (\%) } & \multicolumn{3}{|c|}{ Bulk density $\left(\mathrm{Mg} \mathrm{m}^{-3}\right)$} \\
\hline & & $\mathbf{A}$ & B & $\mathbf{C}$ & A & B & C \\
\hline Maize - Fallow & 19.7 & 68.9 & 66.8 & 65.8 & 1.28 & 1.32 & 1.36 \\
\hline Maize - Rapeseed & 17.3 & 71.9 & 70.1 & 68.0 & 1.25 & 1.36 & 1.39 \\
\hline Maize - French bean (BT) & 21.4 & 71.2 & 69.0 & 67.3 & 1.28 & 1.25 & 1.37 \\
\hline Maize - French bean $(\mathrm{PT})$ & 19.8 & 72.1 & 68.6 & 67.4 & 1.27 & 1.29 & 1.36 \\
\hline Maize - Black gram & 19.8 & 74.2 & 70.50 & 66.13 & 1.24 & 1.29 & 1.35 \\
\hline $\mathrm{CD}(p=0.05)$ & 1.00 & 3.42 & 3.83 & NS & 0.03 & NS & NS \\
\hline \multicolumn{8}{|c|}{ Soil moisture conservation measures } \\
\hline No mulch (Mo) & 18.49 & 68.3 & 66.1 & 63.4 & 1.27 & 1.35 & 1.40 \\
\hline In-situ Maize stalk mulch $\left(\mathrm{M}_{1}\right)$ & 19.39 & 71.5 & 68.1 & 66.3 & 1.26 & 1.37 & 1.37 \\
\hline $\mathrm{M}_{1}+$ Ambrosia artemisiifolia $\left(\mathrm{M}_{2}\right)$ & 20.01 & 72.4 & 69.9 & 67.7 & 1.27 & 1.34 & 1.35 \\
\hline $\mathrm{M}_{1}+$ Tephrosia purpurea $\left(\mathrm{M}_{3}\right)$ & 20.53 & 74.5 & 71.9 & 70.3 & 1.25 & 1.34 & 1.35 \\
\hline $\mathrm{CD}(p=0.05)$ & 0.89 & 4.33 & 4.03 & 5.49 & NS & NS & NS \\
\hline
\end{tabular}

BT-Bush type, PT-Pole type, SMC -Soil moisture stock, WHC - Water holding capacity, CD $(P=0.05)$ - Critical difference, NS- Non-significant, A- 0-15 cm, B-15-30 cm, C- $30-45 \mathrm{~cm}$

Table.3 Interaction effect on maize equivalent yield $\left(\mathrm{t} \mathrm{ha}^{-1}\right)$ as influence by cropping systems and SMC measures

\begin{tabular}{lcccccc}
\hline Treatments & $\begin{array}{c}\text { Maize - } \\
\text { Fallow }\end{array}$ & $\begin{array}{c}\text { Maize - } \\
\text { Rapeseed }\end{array}$ & $\begin{array}{c}\text { Maize }- \\
\text { French } \\
\text { bean } \\
(\mathbf{B T})\end{array}$ & $\begin{array}{c}\text { Maize }- \\
\text { French } \\
\text { bean } \\
(\mathbf{P T})\end{array}$ & $\begin{array}{c}\text { Maize - } \\
\text { Black } \\
\text { gram }\end{array}$ & Mean \\
\hline Mo & 3.06 & 4.31 & 6.42 & 7.22 & 5.58 & $\mathbf{4 . 7}$ \\
$\mathrm{M}_{1}$ & 3.11 & 4.53 & 6.59 & 8.01 & 6.25 & $\mathbf{5 . 1}$ \\
$\mathrm{M}_{2}$ & 3.13 & 4.56 & 7.14 & 8.83 & 6.93 & $\mathbf{5 . 5}$ \\
$\mathrm{M}_{3}$ & 3.17 & 4.75 & 7.94 & 9.50 & 7.46 & $\mathbf{5 . 9}$ \\
Mean & $\mathbf{3 . 1 2}$ & $\mathbf{4 . 5 4}$ & $\mathbf{7 . 0 2}$ & $\mathbf{8 . 3 9}$ & $\mathbf{6 . 5 5}$ & \\
& & & & $\mathbf{S E}(\mathbf{m}) \pm$ & $\mathbf{C D}(\boldsymbol{p}=\mathbf{0 . 0 5})$ \\
Cropping systems & & & & $\mathbf{0 . 1 0}$ & $\mathbf{0 . 3 3}$ & \\
SMC measures & & & & $\mathbf{0 . 0 7}$ & $\mathbf{0 . 2 0}$ & \\
For SMC at same or different level of CS & & $\mathbf{0 . 1 5}$ & $\mathbf{0 . 4 8}$ & \\
For CS at different level of SMC & & & $\mathbf{0 . 1 4}$ & $\mathbf{0 . 4 0}$ &
\end{tabular}

BT-bush type, PT-pole type, CS- Cropping system, SMC- Soil moisture conservation, SE (m) \pm -Standard error of mean, $\mathrm{CD}(p=0.05)$ - Critical difference 
Fig.1 Soil moisture content at 0-15 cm, 15-30 cm and 30-45 cm soil depth as influenced by cropping systems from sowing to harvest. Note: BT-Bole type, PT-Pole type, SMC-Soil moisture conservation, DAS-Day after sowing, MSM- Maize stalk mulch
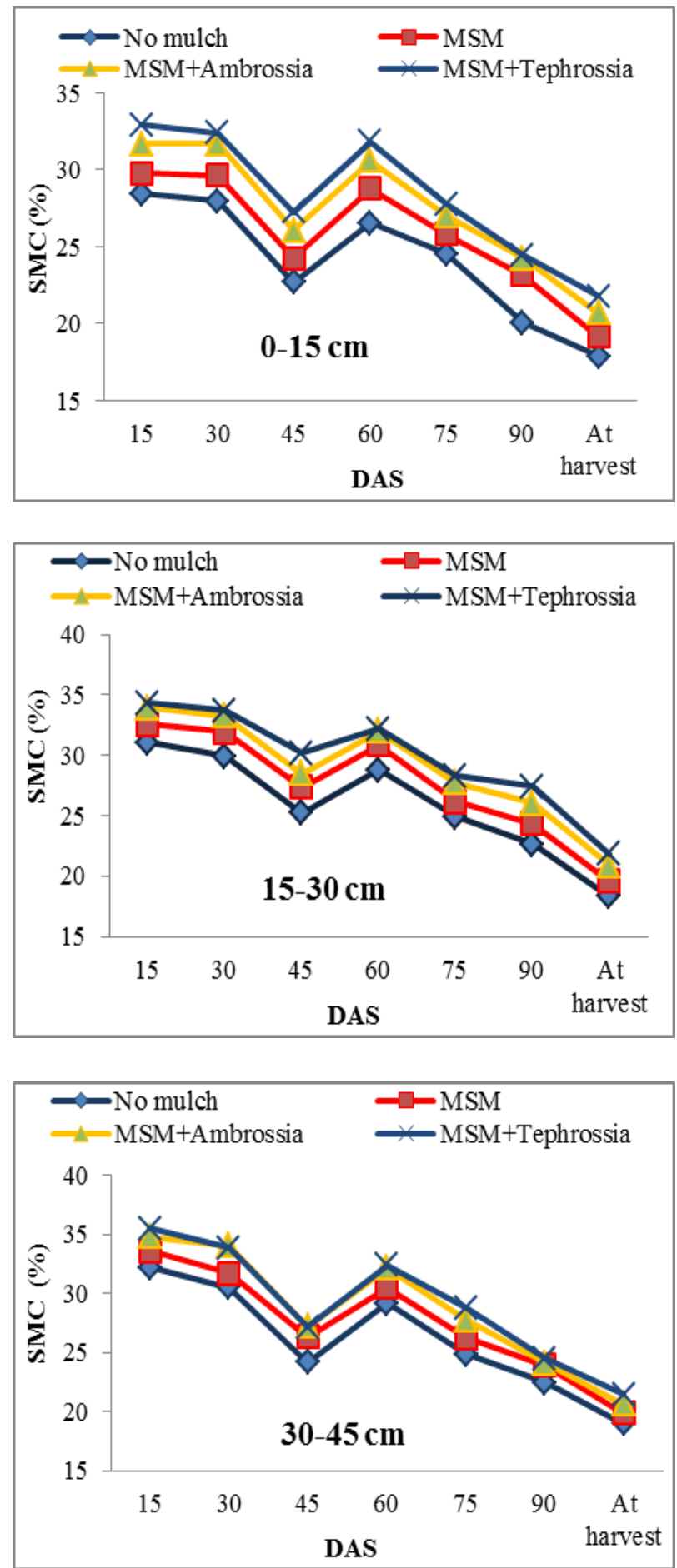
Fig.2 Soil moisture content as influenced by soil moisture conservation measures at 0-15 cm, 15$30 \mathrm{~cm}$ and 30-45 cm depth from sowing to harvest. Note: BT-Bole type, PT-Pole type, SMCSoil moisture conservation, DAS-Day after sowing, MSM- Maize stalk mulch
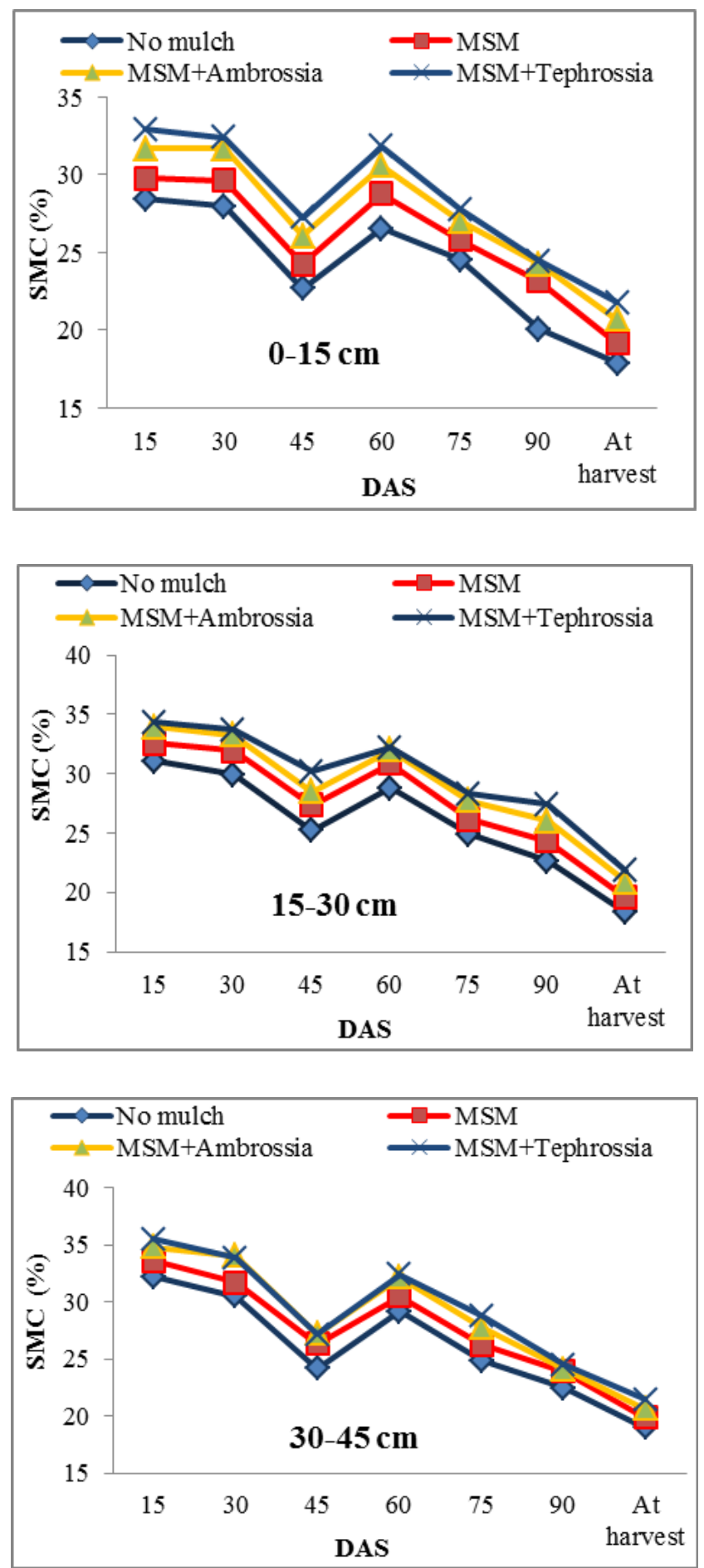


\section{Water holding capacity and bulk density}

Significant influence of cropping systems and SMC measure were recorded on WHC. Maximum WHC was observed under maizeblack gram system followed by maize-French bean (PT) system. Higher BD under no- till than conventional tillage would have increased soil WHC; in association with reduced water evaporation from the soil surface due to residue cover would have enhanced available water for the crop (DeVita et al., 2007). Lui et al., (2013) reported that straw mulching is an effective practice for increasing the soil WHC. Significant effect of cropping systems on BD at $0-15 \mathrm{~cm}$ and non-significant effect at $15-30 \mathrm{~cm}$ and 30 $45 \mathrm{~cm}$ depth were observed. Maize-black gram system recorded the lowest soil BD $\left(1.24 \mathrm{Mg} \mathrm{m}^{-3}\right)$ followed by maize-rapeseed system $\left(1.25 \mathrm{Mg} \mathrm{m}^{-3}\right)$. In general, BD increased with increase in soil depth (Table 2). In the similar way, Ghuman et al., (2001) concluded that mulching decreases BD of the surface soil.

In case of SMC measures, non-significant effect on BD was observed at all the depths. At deeper layer from $15-45 \mathrm{~cm}$ the BD ranged from 1.25 to $1.40 \mathrm{Mg} \mathrm{m}^{-3}$ under no mulch. The highest BD was recorded in soil under residue removal at all depths and lower $\mathrm{BD}$ was observed at $0-15 \mathrm{~cm}$ where $\mathrm{M}_{1}+$ Tephrosia purpurea mulching practiced $\left(1.25 \mathrm{Mg} \mathrm{m}^{-3}\right)$. Similar BD was found under $\mathrm{M}_{1}+$ Tephrosia purpurea and $\mathrm{M}_{1}+$ Ambrosia artemisiifolia mulch at 0-15 and $15-30 \mathrm{~cm}$, respectively.

\section{Effect on maize equivalent yield (MEY)}

Interaction effect of cropping systems and SMC measures on MEY was significant (Table 3). The maximum MEY was obtained under maize-french bean (PT) cropping system with the retention of maize stalk mulch along with Tephrosia purpurea mulch
(9.5 $\mathrm{t} \mathrm{ha}^{-1}$ ) followed by $\mathrm{M}_{1}+$ Ambrosia artemisiifolia mulch $\left(8.83 \mathrm{t} \mathrm{ha}^{-1}\right)$. Choudhary and Kumar, (2013) also reported higher MEY in maize- French bean system due to higher market price of French bean.

The present investigation implied that the double layer mulching with in-situ maize stalk and fresh weed biomass of Ambrosia artemisiifolia or Tephrosia purpurea is a viable and recommendable practice for soil moisture conservation and enhanced yield of rabi crops over non mulching under maize based cropping system in mid-altitudes of Meghalaya. Hence, the present study clearly and consistently substantiates the role of mulching in different rabi crops by achieving higher yield, conserving increased soil moisture with improved soil physical properties under maize based cropping system of $\mathrm{NEH}$ region.

\section{References}

Blake, G.R. and Hartge, K.H. 1986. Bulk density. In: Klute, A. (Ed.), Methods of Soil Analysis, Part I, ASA Monograph No. 9. Lewis Publishers, Madison, WI, pp. 363- 376.

Blanco, H and Lal, R. 2008. Principles of soil conservation and management. Springer Publ. Co., New York.

Choudhary, V.K. and Suresh, K.P. 2013. Crop and water productivity, profitability and energy consumption pattern of a maize-based crop sequence in the North Eastern Himalayan Region, India. Archives Agronomy Soil Sci., 59(5): 653-669.

De-Vita, P., Di Paolo, E., Fecondo, G., Di Fonz, O. N. and Pisante. M. 2007. Notillage and conventional tillage effects on durum wheat yield, grain quality and soil moisture content in southern Italy. Soil and Tillage Res., 92(1-2): 69-78. 
Jalota, S.K., Khera, R. and Ghuman, B.S. 1998. Method in soil physics. Narosa publishing House, New Delhi. pp: 6567.

Liu Yang., Maosheng, Gao., Wei, Wua., Sikander Khan. Tanveer., Xiaoxia, Wena, Yuncheng Liao. 2013. The effects of conservation tillage practices on the soil water-holding capacity of a non-irrigated apple orchard in the Loess Plateau, China. Soil and Tillage Res., 130: 7-12.

Nalayini, P., Anandham, R., Sankaranarayanan, K. and Rajendran, T. P. 2009. Polyethylene mulching for enhancing crop productivity and water use efficiency in cotton (Gossypium hirsutum) and maize (Zea mays) cropping system. Indian J. Agronomy, 54(4): 409-414.

Obalum, S.E, Igwe, C.A., and Obi, M.E. 2010. Moisture dynamics in selected layers of a course-textured mineral soil as induced by tillage-mulch practices under sorghum and soybean at Nsukka, Southern Nigeria. Res. J. Soil and Water Management, 1(2): 45-
60.

Pervaiz, M.A., Iqbal, M., Shahzad, K. and Anwar-UI-Hussan. 2009. Effect of mulch on soil physical properties and N P K concentration in maize (Zea mays) shoots under two tillage system. Int. J. Agri. and Biol., 11(2): 119-124.

Rathore, A.L., Pal, A.R. and Sahu, K.K. 1998. Tillage and mulching effects on water use, root growth and yield of rainfed mustard and chickpea grown after lowland rice. J. Sci. Food and Agri., 78: 149-161.

Sharma, A.R., Singh, R., Dhyani, S.K. and Dube, R.K. 2010. Effect of live mulching with annual legumes on performance of maize (Zea mays) and residual effect on following wheat (Triticum aestivum). Indian $J$. Agronomy, 55(3): 177-84.

Singh, M.K., Lal, R., Merrie, and AnnVarughese. 2013. Twenty two years of tillage and mulching impacts on soil physical characteristics and carbon sequestration in Central Ohio. Soil and Tillage Res., 126: 151-158.

\section{How to cite this article:}

Bidyapati Ngangom, Anup Das, Savita and Krishnappa, R. 2017. Soil Physical Properties and Productivity as Influenced by Soil Moisture Conservation Measures under Maize Based Cropping System in Acid Soils of North East India. Int.J.Curr.Microbiol.App.Sci. 6(3): 428436. doi: https://doi.org/10.20546/ijcmas.2017.603.049 